\title{
Investigation of biochemical characters and antioxidant properties of different winged bean (Psophocarpus tetragonolobus) genotypes grown in Indonesia
}

\author{
JANSON CALVINDI ${ }^{1}$, MUHAMAD SYUKUR ${ }^{2}$, WARAS NURCHOLIS ${ }^{1,3, \bullet}$ \\ ${ }^{1}$ Department of Biochemistry, Faculty of Mathematics and Natural Sciences, Institut Pertanian Bogor. Jl. Agatis, Kampus IPB Darmaga, Bogor 16680, \\ West Java, Indonesia. Tel. +62-251-8629353, ’email: wnurcholis@ apps.ipb.ac.id \\ ${ }^{2}$ Department of Agronomy and Horticulture, Faculty of Agriculture, Institut Pertanian Bogor. Jl. Meranti, Kampus IPB Darmaga, Bogor 16680, West \\ Java, Indonesia \\ ${ }^{3}$ Tropical Biopharmaca Research Center, Institut Pertanian Bogor. Jl. Taman Kencana, Bogor 16128, West Java, Indonesia
}

Manuscript received: 26 February 2020. Revision accepted: 10 May 2020.

\begin{abstract}
Calvindi J, Syukur M, Nurcholis W. 2020. Investigation of biochemical characters and antioxidant properties of different winged bean (Psophocarpus tetragonolobus) genotypes grown in Indonesia. Biodiversitas 21: 2420-2424. Winged bean, Psophocarpus tetragonolobus (L) DC, is described as having antioxidant properties. This work evaluated the biochemical and antioxidant characteristics of the P. tetragonolobus genotypes. Twelve-winged bean genotypes were calculated for total phenolic content (TPC) and total flavonoid content (TFC) of biochemical characters and antioxidant properties by using four methods: 2,2-diphenyl picrylhydrazyl (DPPH), cupric reducing antioxidant power (CUPRAC), ferric reducing antioxidant power (FRAP), and Trolox equivalent antioxidant capacity (TEAC). The plant material was grown in the same location conditions in Indonesia. The total phenolic content varied from 154.6 to $161.5 \mathrm{mg}$ GAE/ $100 \mathrm{~g}$, and flavonoid ranged from 105.2 to $112.4 \mathrm{mg}$ QE/ $100 \mathrm{~g}$ fresh weight. The antioxidant capacities were 30.6 - 47.0, 140.4 - 167.6, 66.9 - 170.8, and 28.0 - $52.4 \mu \mathrm{mol}$ TE/ $100 \mathrm{~g}$ fresh weight as calculated by the DPPH, TEAC, FRAP, and CUPRAC assays, respectively. The antioxidant activities were significantly correlated with the polyphenol content of winged bean genotypes fruits. The genotypes TU, L3, H3U, H1P, and TH were recognized higher based on their TPC, TFC, and antioxidant activities, indicating that these genotypes to be promising for further breeding program and commercial purposes.
\end{abstract}

Keywords: Agricultural biochemistry, antioxidant, flavonoid, polyphenol, winged bean

\section{INTRODUCTION}

Winged bean (Psophocarpus tetragonolobus; FamilyFabaceae $)$ is a diploid $(2 \mathrm{n}=2 \mathrm{X}=18)$ underutilized legume crop and is widely cultivated in Asia and Africa (Ng, 2013; Mohanty et al. 2020). Winged bean is called as "soybean of tropics" with excessive potentiality the nutritional contents (Amoo et al. 2011). The flowers, leaves, tubers, pods, and seeds of plant parts are eatable (Mohanty et al. 2020). The essential amino acids, proteins, vitamins, minerals, and oil contents in winged bean seed are similar to soybean (Amoo et al. 2011). Moreover, the winged bean was found for containing anti-nutrients such as polyphenol (Singh et al. 2019), tannin (Singh et al. 2017), phytic acid, trypsin inhibitor, chymotrypsin inhibitor (Mohanty et al. 2020), protease inhibitor (Kaur and Sohal 2019), and oxalate (Alalade et al. 2016). Traditionally, the winged bean is used to treat diabetes, cancer, infection, eye and migraine diseases, muscle weakness, and asthma (Singh et al. 2019). Previously, several studies have been reported pharmacological activities of winged beans, such as an antioxidant (Koley et al. 2019; Singh et al. 2019), antihypertensive (Chay et al. 2018) and antifungal (Zakuan et al. 2018).

Reactive oxygen species, a free radical, is destructive to persons, leading to digestive, cardiovascular, cancer, and respiratory diseases (Liu et al. 2018). The vegetables and fruits are rich in antioxidant compounds. Consuming them will help to protect against several diseases caused by free radicals ( $\mathrm{Li}$ et al. 2014; Ishihara et al. 2018). The function of plant antioxidants is to defend the cell from free radicals and regulate reactive oxygen species-related enzymes (Djordjevic et al. 2011). The synthetic antioxidant of butylated hydroxyanisole and butylated hydroxytoluene are promoted carcinogenesis (Devi et al. 2019). Their consumption has now been a decline. Thus, the finding of natural antioxidants with non-toxic compounds is important to be done. Winged bean is rich in metabolite with antioxidant properties, including peptide (Wan Mohtar et al. 2014), phenolic acid, and flavonoid (Gan et al. 2016; Singh et al. 2019). Olaiya et al. (2018) reported that different winged bean accessions have variate antioxidant properties.

The work aimed to determine the biochemical characters and antioxidant properties of twelve-winged bean genotypes, including total phenolic content (TPC) and total flavonoid content (TFC) for biochemical characteristics, and 2,2-diphenyl picrylhydrazyl (DPPH), cupric reducing antioxidant power (CUPRAC), ferric reducing antioxidant power (FRAP), and Trolox equivalent antioxidant capacity (TEAC) for antioxidant activities. Besides, we predicted the variation and association between 
the biochemicals characters and antioxidant properties in winged bean genotypes. So, this work could be provided scientific information knowledge in the selection, improvement, and breeding of different winged bean genotypes.

\section{MATERIALS AND METHODS}

\section{Plant material and sample preparation}

Twelve-winged bean genotypes germplasm were selected in the F6 population, which derived from crossing (F1) of Thailand-introduced purple winged bean x Cilacapaccessed local green-winged bean (Table 1). The genotypes were cultivated in the experimental fields of Bogor Agricultural University, Bogor, West Java, Indonesia. The cultivation was performed in a randomized block design in three replications. For biochemical determination components (total phenolic and flavonoid) and antioxidant capacities, the sample fruits of studied genotypes were harvested at $10^{\text {th }}$-day pod after anthesis. The sample preparation was extracted using ethanol according to the method recommended by Singh et al. (2019) with slight modification. Briefly, after the pod sample was cut into minor pieces, then the seeds were removed. After the sample was homogenized for 2 min using the blender, $2 \mathrm{~g}$ sample each genotype was extracted with $80 \%$ ethanol (10 $\mathrm{ml}$ ). The sample was sonicated for $30 \mathrm{~min}$, then macerated with stirring at $125 \mathrm{rpm}$ for $24 \mathrm{~h}$ in the dark. Then, the sample homogenate was centrifuged (at 10000xg and $4^{\circ} \mathrm{C}$ ) for $15 \mathrm{~min}$. Finally, the sample extract (supernatant) concentration of $0.2 \mathrm{~g} / \mathrm{ml}$ was used for the determination of total phenolic content (TPC), total flavonoid content (TFC), and antioxidant activity.

\section{Biochemical and antioxidant analyses}

Extract fruit samples were determined total phenolic and total flavonoid contents for biochemical traits evaluation. TPC was assessed spectrophotometrically using Folin-Ciocalteu reagent with the method recommended by Khumaida et al. (2019) with modification. TPC was measured based on the standard curve and expressed as mg gallic acid equivalents (GAE) / $100 \mathrm{~g}$ fresh weight (FW). Supernatant extracts each genotype $(20 \mu \mathrm{L})$ were mixed with $50 \%$ Folin-Ciocalteu reagent $(100 \mu \mathrm{L})$ in 96 -well microplate and incubated for $5 \mathrm{~min}$. Then, the mixture was added with $7.5 \% \mathrm{Na}_{2} \mathrm{CO}_{3}(80 \mu \mathrm{L})$ and incubated in the dark for $2 \mathrm{~h}$. Finally, the absorbance at $750 \mathrm{~nm}$ was measured with a microplate reader (Epoch BioTek, USA). Whereas TFC was determined using the colorimetric method (Khumaida et al. 2019) with quercetin as standard. TFC expressed as mg QE/ $100 \mathrm{~g}$ FW. The sample or diluted standard $(10 \mu \mathrm{L})$ was mixed with methanol $(60 \mu \mathrm{L}), 10 \%$ $\mathrm{AlCl} 3(10 \mu \mathrm{L}), 1 \mathrm{M} \mathrm{CH} 3 \mathrm{COOK}(10 \mu \mathrm{L})$, and distilled water $(110 \mu \mathrm{L})$. The mixtures were incubated for $30 \mathrm{~min}$ at room temperature and then the absorbance of mixture was measured at $415 \mathrm{~nm}$ using microplate reader (Epoch BioTek, USA).
Table 1. Information of winged bean genotypes used in this work

\begin{tabular}{lll}
\hline $\begin{array}{c}\text { Genotype } \\
\text { codes }\end{array}$ & \multicolumn{1}{c}{ Origin } & Pod color \\
\hline H1U & Selected (F6) & Green \\
H2 & Selected (F6) & Green \\
H3P & Selected (F6) & Green \\
H1P & Selected (F6) & Green \\
H3U & Selected (F6) & Green \\
L4 & Selected (F6) & Purple \\
L2 & Selected (F6) & Purple \\
H4P & Selected (F6) & Green \\
L1 & Selected (F6) & Purple \\
L3 & Selected (F6) & Purple \\
TU & Parent (Thailand-introduced & Purple \\
& purple winged bean) & \\
TH & Parent (Cilacap-accessed local & Green \\
& green winged bean) & \\
\hline
\end{tabular}

Four in-vitro methods were used to evaluate the antioxidant capacities of extract fruit samples of winged bean genotypes. The assays are 22-diphenyl picrylhydrazyl (DPPH) and Trolox equivalent antioxidant capacity (TEAC) for evaluating the free radical scavenging activities, and cupric reducing antioxidant power (CUPRAC) and ferric reducing antioxidant power (FRAP) for assessing the reducing power. DPPH, TEAC, FRAP, and CUPRAC were determined.

The DPPH radical scavenging activity was measured as explained by Nurcholis et al. (2017) with modification. DPPH $(125 \mu \mathrm{M})$ in ethanol was used in the experiment. Briefly, $100 \mu \mathrm{L}$ aliquot extract was mixed with DPPH (100 $\mu \mathrm{L}$ ) and then incubated at room temperature (dark) for 30 min. Final absorbance was measured at $517 \mathrm{~nm}$ using a microplate reader (Epoch BioTek, USA). The value was expressed as $\mu \mathrm{mol}$ Trolox equivalent per $100 \mathrm{~g} \mathrm{FW}$.

TEAC of the sample was determined using 2, 2-azinodi-(3-ethylbenzothialozinesulphonic acid (ABTS) radical according Re et al. (1999) with modification. Briefly, 20 $\mu \mathrm{L}$ aliquot extract was mixed with seven mM ABTS reagent $(280 \mu \mathrm{L})$. The mixture incubated in the dark for 6 min. Absorbance was measured using a microplate reader (Epoch BioTek, USA) at $734 \mathrm{~nm}$. The result was expressed as $\mu$ mol Trolox equivalent per $100 \mathrm{~g} \mathrm{FW}$.

Ferric reducing antioxidant power (FRAP) was estimated as described by Benzie and Strain (1996) with modification. FRAP reagent consisted of $10 \mathrm{mM}$ TOTZ in $40 \mathrm{mM} \mathrm{HCl}, 20 \mathrm{mM} \mathrm{FeCl} 3.6 \mathrm{H} 2 \mathrm{O}$ in distilled water, and acetate buffer at $\mathrm{pH} 3.6$, in comparison to 1: 1: 10 , respectively. Before used, the FRAP reagent was stored at $37^{\circ} \mathrm{C}$ for $30 \mathrm{~min}$. Briefly, $10 \mu \mathrm{L}$ aliquot extract was mixed with $300 \mu \mathrm{L}$ FRAP reagent and then incubated at $37^{\circ} \mathrm{C}$ for $30 \mathrm{~min}$ in the dark. The absorbance at $593 \mathrm{~nm}$ was measured using a microplate reader (Epoch BioTek, USA) at $734 \mathrm{~nm}$. Antioxidant activity was expressed as $\mu \mathrm{mol}$ Trolox equivalent per $100 \mathrm{~g} \mathrm{FW}$.

CUPRAC method was determined as described by Öztürk et al. (2011) with modification. Briefly, the sample $(50 \mu \mathrm{L})$ was mixed with $50 \mu \mathrm{L}$ each of neocuproine $(7.5 \mathrm{x}$ 
$\left.10^{-3} \mathrm{M}\right)$, copper (II) chloride $\left(10^{-2} \mathrm{M}\right)$, and ammonium acetate buffer $(\mathrm{pH} 7)$ solutions. After the mixture incubated in the dark for $30 \mathrm{~min}$, the absorbance was recorded at 450 $\mathrm{nm}$, and value was expressed as $\mu \mathrm{mol}$ Trolox equivalent per $100 \mathrm{~g} \mathrm{FW}$.

\section{Data analysis}

The means value \pm SD of three replicates were determined. ANOVA was performed using ExpDes packages in R, followed by the Scott-Knott test (Ferreira et al. 2014). The PerformanceAnalytics packages in $\mathrm{R}$ was used to create the Pearson correlation coefficients between biochemical and antioxidant variables (Peterson et al. 2014).

\section{RESULTS AND DISCUSSION}

The biochemical components and antioxidant capacities of different winged bean genotypes, including TPC, TFC, FRAP, CUPRAC, DPPH, and TEAC are presented in Table 2.

Polyphenol is a group of biochemistry compounds that have antioxidant properties (Khumaida et al. 2019; Kalisz et al. 2020). Flavonoid is one of the polyphenol compounds and is widely reported as antioxidant activity (Nurcholis et al. 2016; Tanleque-Alberto et al. 2020). Significant variances of TPC and TFC of studied winged bean genotypes were observed in the present work (Table 1). The highest TPC was recorded as $161.5 \mathrm{mg}$ GAE/ $100 \mathrm{~g}$ FW in TU genotype, and the lowest was noted in $\mathrm{H} 3 \mathrm{P}$ genotype as $154.6 \mathrm{mg} \mathrm{GAE} / 100 \mathrm{~g} \mathrm{FW}$. In this work, TFC in the twelve-winged bean genotypes was significantly different, with the maximum value recorded in L3 (112.4 $\mathrm{mg} \mathrm{QE} / 100 \mathrm{~g} \mathrm{FW}$ ) and the minimum recorded in $\mathrm{H} 3 \mathrm{P}$ (105.2 mg QE/ $100 \mathrm{~g} \mathrm{FW).} \mathrm{TPC} \mathrm{and} \mathrm{TFC} \mathrm{in} \mathrm{this} \mathrm{study} \mathrm{are}$ satisfactorily higher compared to the phenol and flavonoid content recorded in the works performed by Singh et al. (2019) for winged bean genotypes from India with value ranged from 48.4 to $143.5 \mathrm{mg} \mathrm{GAE} / 100 \mathrm{~g} \mathrm{FW}$ and 9.1 to $37.0 \mathrm{mg} \mathrm{CE} / 100 \mathrm{~g} \mathrm{FW}$, respectively. In date, plant phenol and flavonoid metabolites have found significant interest, because of the usefulness in overcoming several human diseases (Vauzour et al. 2010; Ma and Chen 2020). Thus, it is recommended that the winged bean genotypes having high TPC and TFC should be nominated for bred in further development.

The antioxidant activities among 12 selected genotypes were observed, which is seen in Table 1. Antioxidant activity depends on the mechanism of antioxidant metabolites in extract (Mercado-Mercado et al. 2020). Thus, different assays are needed to evaluate natural antioxidant capacity. In this study, FRAP, CUPRAC, DPPH, and TEACH methods are applied to assess the antioxidant capacity of studied winged bean genotypes. Free radical scavenging activity of the winged bean genotypes was evaluated using TEAC and DPPH assays (Mareček et al. 2017), whereas reducing power was performed using CUPRAC and FRAP assays (Suktham et al. 2019). The antioxidant activities among the winged bean genotypes were varied from 66.9 to $170.8 \mu \mathrm{mol}$ TE/ $100 \mathrm{~g} \mathrm{FW}$, as measured by the FRAP method. In the CUPRAC method, the antioxidant activity of studied genotypes ranged from 28.0 to $52.4 \mu$ mol TE/ $100 \mathrm{~g} \mathrm{FW}$. The genotype H3U was the highest antioxidant capacity, whereas lowest noted in genotype TH based on FRAP and CUPRAC assays. In TEAC assay, the antioxidant capacity of the selected genotypes varied from 140.4 (H1U) to 167.6 (TH) $\mu$ mol TE/ $100 \mathrm{~g} \mathrm{FW,} \mathrm{whereas} \mathrm{DPPH} \mathrm{method} \mathrm{values}$ ranged between 32.8 (TU) to 47.0 (H1P) $\mu$ mol TE/ $100 \mathrm{~g}$ FW. Genotype H3U, H1P, and TH showed the highest performance for their antioxidant capacities. Thus, these genotypes are recommended in future plant breeding of winged bean based on antioxidant capacities. Antioxidant activity with FRAP and CUPRAC assays showed highest compared with DPPH and TEAC assays in studied winged bean genotypes. These results were linear with formerly reported findings by (Singh et al. (2019) with studied genotypes from India. Therefore, antioxidant activity in winged bean extract dominant showed reducing power than free radical scavenging activity.

Table 2. Biochemical component and antioxidant properties of different winged bean genotypes

\begin{tabular}{|c|c|c|c|c|c|c|}
\hline \multirow{2}{*}{ Genotypes } & TPC & TFC & FRAP & CUPRAC & DPPH & TEAC \\
\hline & (mg GAE/100 g FW) & $(\mathrm{mg} \mathrm{QE} / 100 \mathrm{~g} \mathrm{FW})$ & $(\mu \mathrm{mol}$ TE/100 g FW $)$ & $(\mu \mathrm{mol}$ TE/100 g FW $)$ & $(\mu \mathrm{mol}$ TE/100 g FW $)$ & $(\mu \mathrm{mol}$ TE/100 g FW $)$ \\
\hline $\mathrm{H} 1 \mathrm{U}$ & $159.2 \pm 0.3 \mathrm{a}$ & $107.5 \pm 2.0 \mathrm{c}$ & $119.4 \pm 38.0 b$ & $46.3 \pm 2.2 b$ & $35.5 \pm 1.7 \mathrm{c}$ & $140.4 \pm 2.2 \mathrm{~d}$ \\
\hline $\mathrm{H} 2$ & $157.2 \pm 0.8 \mathrm{a}$ & $105.6 \pm 0.7 d$ & $89.9 \pm 15.9 c$ & $37.7 \pm 1.2 \mathrm{~d}$ & $38.4 \pm 1.4 \mathrm{c}$ & $161.6 \pm 4.0 \mathrm{~b}$ \\
\hline H3P & $154.6 \pm 0.8 b$ & $105.2 \pm 0.3 d$ & $76.0 \pm 15.7 \mathrm{c}$ & $31.8 \pm 1.6 \mathrm{e}$ & $34.7 \pm 0.3 c$ & $166.3 \pm 0.5 \mathrm{a}$ \\
\hline $\mathrm{H} 1 \mathrm{P}$ & $154.8 \pm 0.0 b$ & $105.3 \pm 0.7 d$ & $75.5 \pm 15.5 c$ & $34.5 \pm 3.7 d$ & $47.0 \pm 6.8 \mathrm{a}$ & $164.0 \pm 1.9 b$ \\
\hline $\mathrm{H} 3 \mathrm{U}$ & $158.1 \pm 1.8 \mathrm{a}$ & $107.1 \pm 2.1 \mathrm{c}$ & $170.8 \pm 26.0 a$ & $52.4 \pm 4.0 \mathrm{a}$ & $30.6 \pm 2.6 \mathrm{~d}$ & $146.5 \pm 3.5 \mathrm{~d}$ \\
\hline L4 & $157.9 \pm 1.9 a$ & $109.5 \pm 0.2 b$ & $106.0 \pm 23.5 b$ & $38.5 \pm 0.7 \mathrm{~d}$ & $36.3 \pm 0.6 c$ & $160.5 \pm 2.0 \mathrm{~b}$ \\
\hline $\mathrm{L} 2$ & $157.9 \pm 1.9 a$ & $108.6 \pm 12.1 \mathrm{~b}$ & $117.4 \pm 23.8 b$ & $46.5 \pm 3.6 b$ & $37.2 \pm 3.1 \mathrm{c}$ & $155.0 \pm 3.5 \mathrm{c}$ \\
\hline $\mathrm{H} 4 \mathrm{P}$ & $157.5 \pm 0.7 a$ & $108.6 \pm 0.3 b$ & $93.0 \pm 10.2 c$ & $36.6 \pm 4.1 d$ & $42.5 \pm 1.3 b$ & $162.2 \pm 1.6 b$ \\
\hline L1 & $159.7 \pm 2.0 \mathrm{a}$ & $107.7 \pm 1.5 c$ & $118.0 \pm 18.7 \mathrm{~b}$ & $43.0 \pm 2.7 \mathrm{c}$ & $37.0 \pm 1.4 \mathrm{c}$ & $143.7 \pm 0.4 \mathrm{~d}$ \\
\hline L3 & $157.0 \pm 0.8 \mathrm{a}$ & $112.4 \pm 1.1 \mathrm{a}$ & $98.8 \pm 24.0 \mathrm{c}$ & $41.3 \pm 4.9 \mathrm{c}$ & $35.8 \pm 0.6 c$ & $156.4 \pm 1.7 \mathrm{c}$ \\
\hline TU & $161.5 \pm 4.4 a$ & $110.1 \pm 1.2 b$ & $113.3 \pm 7.1 b$ & $48.1 \pm 1.9 b$ & $32.8 \pm 1.2 \mathrm{~d}$ & $143.2 \pm 5.3 \mathrm{~d}$ \\
\hline $\mathrm{TH}$ & $155.2 \pm 0.8 b$ & $105.9 \pm 0.5 \mathrm{~d}$ & $66.9 \pm 5.4 \mathrm{c}$ & $28.0 \pm 1.2 \mathrm{e}$ & $37.6 \pm 2.2 \mathrm{c}$ & $167.6 \pm 0.7 a$ \\
\hline
\end{tabular}

Note: DPPH, 22-diphenyl picrylhydrazyl; CUPRAC, cupric reducing antioxidant power; FRAP, ferric reducing antioxidant power; TEAC, Trolox equivalent antioxidant capacity; TPC, total phenolic content; and TFC, total flavonoid content. The value \pm SD of three replicates. Mean value in each column marked with different letters differ significant at $p<0.05$ by the Scott-Knott test 


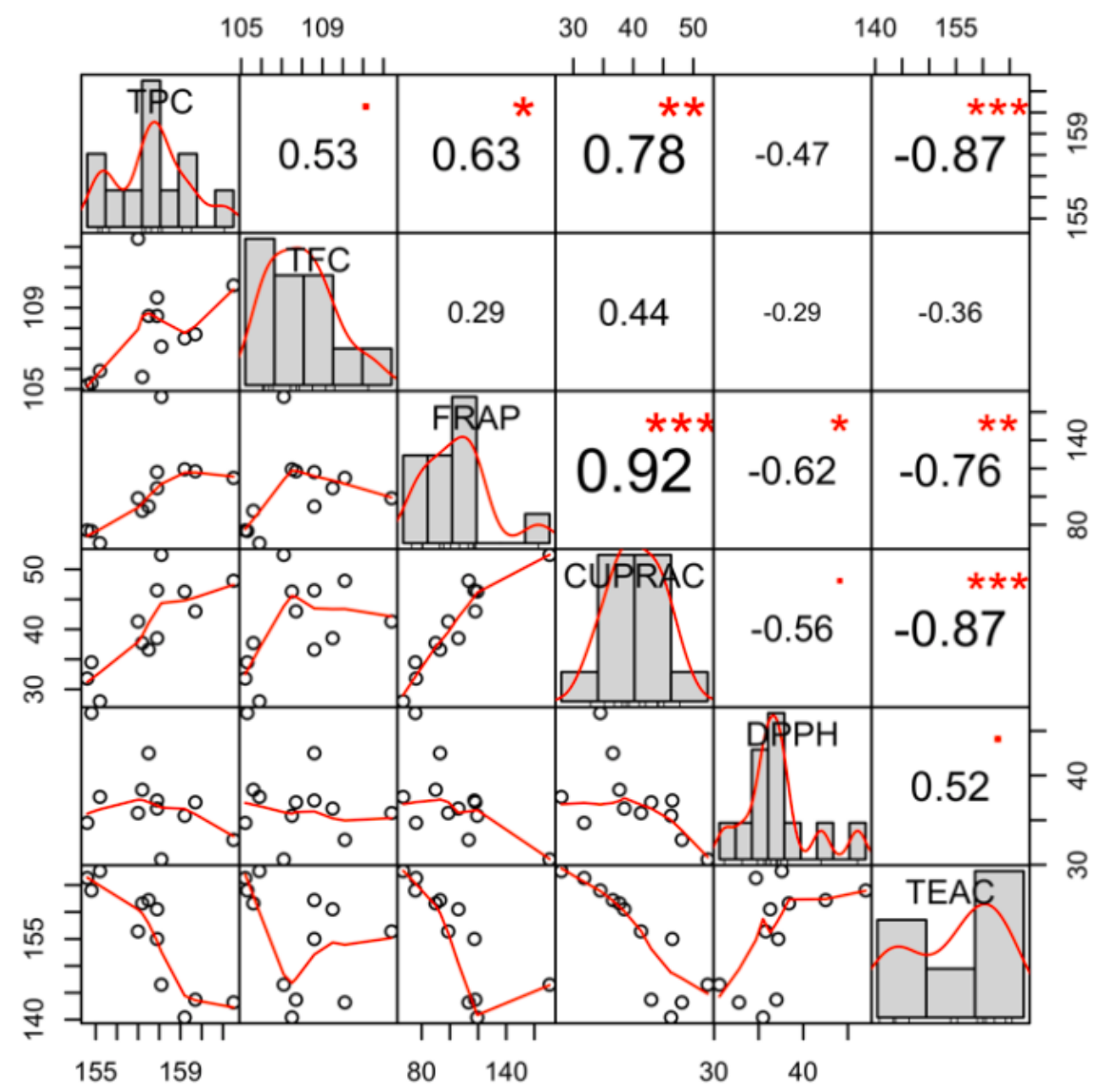

Figure 1. The correlation for total phenolic content (TPC), total flavonoid content (TFC), and antioxidant properties (DPPH, 22diphenyl picrylhydrazyl; CUPRAC, cupric reducing antioxidant power; FRAP, ferric reducing antioxidant power; TEAC, Trolox equivalent antioxidant capacity). ***,**,*, showed significant level with $p$-values of $0.001,0.01,0.05$, and 0.1 , respectively. The figure showed the variable on the diagonal, the bivariate scatter plots with a fitted line on the bottom of the diagonal, and the value of the correlation with the significance level on the top of the diagonal

Polyphenol, such as flavonoid and phenolic content, is a metabolite that often associated with the antioxidant capacities in the plant extract (ZHANG et al. 2018; Lim et al. 2019). Moreover, the flavonoid and phenolic acid metabolites have been shown to be the primary compounds responsible for fruit antioxidant capacities (Wang et al. 2018). As shown in Figure 1, for all the studied genotypes, there were correlations between biochemical variables (TPC and TFC) and antioxidant capacities (DPPH, CUPRAC, FRAP, and TEAC). Positive correlation ( $\mathrm{p}<$ $0.1, \mathrm{r} 2$ value of 0.53 ) were noted between TPC and TFC. In this work, TPC was positive and significantly correlated with the antioxidant capacity of FRAP and CUPRAC assays, whereas negative correlation detected with DPPH and TEAC assays. The result indicated that the antioxidant capacity in winged bean fruit extract might be strongly affected by TPC. This suggests that the phenolic compounds in winged bean were antioxidants of reducing power mechanisms. The lowest positive and negative correlation was detected between TFC and FRAP and CUPRAC assays, and among TFC and DPPH and TEAC assays, respectively. Based on all assays used to evaluate the antioxidant activity, the coefficients of correlation among FRAP/CUPRAC, FRAP/DPPH, and FRAP/TEAC were $0.92,-0.62$, and -0.76 , respectively. The associations between CUPRAC/DPPH and CUPRAC/TEAC were -0.56 and -0.87 , respectively. The correlation between DPPH/TEAC was 0.52. These reports suggest that the antioxidant activity in winged bean fruit can be reliably measured using FRAP and CUPRAC assays than DPPH and TEAC methods.

In summary, the evaluation of the data recorded from this work showed that the antioxidant activities and biochemical characters depended on different winged bean genotypes. The TU, L3, H3U, H1P, and TH genotypes have significantly superior biochemical and antioxidant capacities, which acknowledges us to suggest them for plant breeding and commercial consumption.

\section{ACKNOWLEDGEMENTS}

The authors would like to acknowledge the support received from the Ministry of Research, Technology and Higher Education of the Republic of Indonesia under the PTUPT grant (No. 3/E1/KP.PTNBH/2019). We expressed 
our acknowledgment and appreciation to Kalvin Laia for their kind assistance during the cultivation, harvesting, and sortation of the fruit material used.

\section{REFERENCES}

Alalade JA, Akinlade JA, Aderinola OA, Fajemisin AN, Muraina TO, Amoo TA. 2016. Proximate, mineral and anti-nutrient contents in Psophocarpus tetragonolobus (L.) DC. (Winged Bean) leaves. Br J Pharm Res 10 (2): 1-7.

Amoo I, Adebayo O, Oyeleye A. 2011. Chemical evaluation of winged beans (Psophocarpus tetragonolobus), pitanga cherries (Eugenia uniflora) and orchid fruit (Orchid fruit myristica). Afr J Food Agric Dev 6: 1-12.

Benzie IFF, Strain JJ. 1996. The ferric reducing ability of plasma (FRAP) as a measure of "antioxidant power": The FRAP Assay. Anal Biochem 239 (1): 70-76. DOI: 10.1006/abio.1996.0292.

Chay SY, Salleh A, Sulaiman NF, Zainal Abidin N, Hanafi MA, Zarei M, Saari N. 2018. Blood-pressure lowering efficacy of winged bean seed hydrolysate in spontaneously hypertensive rats, peptide characterization and a toxicity study in Sprague-Dawley rats. Food Funct 9 (3): 1657-1671. DOI: 10.1039/c7fo01769c.

Devi J, Sanwal SK, Koley TK, Mishra GP, Karmakar P, Singh PM, Singh B. 2019. Variations in the total phenolics and antioxidant activities among garden pea (Pisum sativum L.) genotypes differing for maturity duration, seed and flower traits and their association with the yield. Sci Hortic (Amsterdam) 244: 141-150. DOI: 10.1016/j.scienta.2018.09.048.

Djordjevic TM, Šiler-Marinkovic SS, Dimitrijevic-Brankovic SI. 2011 Antioxidant activity and total phenolic content in some cereals and legumes. Int J Food Prop 14 (1): 175-184. DOI: 10.1080/10942910903160364.

Ferreira EB, Cavalcanti PP, Nogueira DA. 2014. ExpDes: An R package for ANOVA and experimental designs. Appl Math 5 (19): 2952-2958. DOI: $10.4236 / \mathrm{am} .2014 .519280$.

Gan RY, Deng ZQ, Yan AX, Shah NP, Lui WY, Chan CL, Corke H. 2016. Pigmented edible bean coats as natural sources of polyphenols with antioxidant and antibacterial effects. LWT 73: 168-177. DOI: 10.1016/j.lwt.2016.06.012.

Ishihara J, Umesawa M, Okada C, Kokubo Y, Iso H. 2018. Relationship between vegetables and fruits (antioxidant vitamins, minerals, and fiber) intake and risk of cardiovascular disease. In: Sawyer D, Vasan R (eds.). Encyclopedia of Cardiovascular Research and Medicine. 1st ed. Elsevier, Amsterdam.

Kalisz S, Oszmiański J, Kolniak-Ostek J, Grobelna A, Kieliszek M, Cendrowski A. 2020. Effect of a variety of polyphenols compounds and antioxidant properties of rhubarb (Rheum rhabarbarum). LWT 118: 108775. DOI: 10.1016/j.lwt.2019.108775.

Kaur AP, Sohal SK. 2019. Purified winged bean protease inhibitor affects the growth of Bactrocera cucurbitae. Bull Entomol Res 109 (4): 550558. DOI: 10.1017/S0007485318000913.

Khumaida N, Syukur M, Bintang M, Nurcholis W. 2019. Phenolic and flavonoid content in ethanol extract and agro-morphological diversity of Curcuma aeruginosa accessions growing in West Java, Indonesia. Biodiversitas 20 (3): 656-663.

Koley TK, Maurya A, Tripathi A, Singh BK, Singh M, Bhutia TL, Tripathi PC, Singh B. 2019. Antioxidant potential of commonly consumed underutilized leguminous vegetables. Int J Veg Sci 25 (4): 362-372. DOI: 10.1080/19315260.2018.1519866.

Li S, Chen G, Zhang C, Wu M, Wu S, Liu Q. 2014. Research progress of natural antioxidants in foods for the treatment of diseases. Food Sci Hum Wellness 3 (3): 110-116. DOI: 10.1016/j.fshw.2014.11.002.

Lim YP, Pang SF, Yusoff MM, Abdul Mudalip SK, Gimbun J. 2019. Correlation between the extraction yield of mangiferin to the antioxidant activity, total phenolic and total flavonoid content of Phaleria macrocarpa fruits. J Appl Res Med Aromat Plants 14: 100224. DOI: 10.1016/j.jarmap.2019.100224.

Liu Z, Ren Z, Zhang J, Chuang C-C, Kandaswamy E, Zhou T, Zuo L. 2018. Role of ROS and nutritional antioxidants in human diseases. Front Physiol 9: 477. DOI: 10.3389/fphys.2018.00477.

Ma G, Chen Y. 2020. Polyphenol supplementation benefits human health via gut microbiota: A systematic review via meta-analysis. J Funct Foods. 66: 103829. DOI: 10.1016/j.jff.2020.103829.
Mareček V, Mikyška A, Hampel D, Čejka P, Neuwirthová J, Malachová A, Cerkal R. 2017. ABTS and DPPH methods as a tool for studying antioxidant capacity of spring barley and malt. J Cereal Sci 73: 40-45. DOI: $10.1016 /$ j.jcs.2016.11.004

Mercado-Mercado G, de la Rosa LA, Alvarez-Parrilla E. 2020. Effect of pectin on the interactions among phenolic compounds determined by antioxidant capacity. J Mol Struct 1199: 126967. DOI: 10.1016/j.molstruc.2019.126967.

Mohanty CS, Singh V, Chapman MA. 2020. Winged bean: An underutilized tropical legume on the path of improvement, to help mitigate food and nutrition security. Sci Hortic (Amsterdam) 260: 108789. DOI: 10.1016/j.scienta.2019.108789.

$\mathrm{Ng}$ NQ. 2013. Conserving tropical leguminous food crops. In: Conservation of Tropical Plant Species. Springer, Berlin.

Nurcholis W, Khumaida N, Syukur M, Bintang M. 2016. Variability of total phenolic and flavonoid content and antioxidant activity among 20 Curcuma aeruginosa Roxb. accessions of Indonesia. Asian J Biochem 11 (3): 142-148. DOI: 10.3923/ajb.2016.142.148.

Nurcholis W, Khumaida N, Syukur M, Bintang M. 2017. Evaluation of free radical scavenging activity in ethanolic extract from promising accessions of Curcuma aeruginosa RoxB. Molekul 12 (2): 133-138.

Olaiya CO, Soetan KO, Karigidi KO. 2018. Evaluation of in vitro antioxidant capacities of six accessions of winged beans (Psophocarpus tetragonolobus). EC Nutr 13 (8): 589-595.

Öztürk M, Duru ME, Kivrak Ş, Mercan-Doğan N, Türkoglu A, Özler MA. 2011. In vitro antioxidant, anticholinesterase and antimicrobial activity studies on three Agaricus species with fatty acid compositions and iron contents: A comparative study on the three most edible mushrooms. Food Chem Toxicol 49 (6): 1353-1360. DOI: 10.1016/j.fct.2011.03.019.

Peterson BG, Carl P, Boudt K, Bennett R, Ulrich J, Zivot E. 2014. Performance analytics: Econometric tools for performance and risk analysis. R Package Version 1 (3541): 107.

Re R, Pellegrini N, Proteggente A, Pannala A, Yang M, Rice-Evans C. 1999. Antioxidant activity applying an improved ABTS radical cation decolorization assay. Free Radic Biol Med 26 (9): 1231-1237. DOI: 10.1016/S0891-5849(98)00315-3.

Singh M, Dubey RK, Koley TK, Maurya A, Singh PM, Singh B. 2019. Valorization of winged bean (Psophocarpus tetragonolobus (L.) DC.) by evaluation of its antioxidant activity through chemometric analysis. S A J Bot 121: 114-120.

Singh V, Goel R, Pande V, Asif MH, Mohanty CS. 2017. De novo sequencing and comparative analysis of leaf transcriptomes of diverse condensed tannin-containing lines of underutilized Psophocarpus tetragonolobus (L.) DC. Sci Rep 7: 44733. DOI: 10.1038/srep44733.

Suktham T, Jones A, Soliven A, Dennis GR, Shalliker RA. 2019. A comparison of the performance of the cupric reducing antioxidant potential assay and the ferric reducing antioxidant power assay for the analysis of antioxidants using reaction flow chromatography. Microchem J 149: 104046. DOI: 10.1016/j.microc.2019.104046.

Tanleque-Alberto F, Juan-Borrás M, Escriche I. 2020. Antioxidant characteristics of honey from Mozambique based on specific flavonoids and phenolic acid compounds. J Food Compos Anal 86: 103377. DOI: 10.1016/j.jfca.2019.103377.

Vauzour D, Rodriguez-Mateos A, Corona G, Oruna-Concha MJ, Spencer JPE. 2010. Polyphenols and human health: Prevention of disease and mechanisms of action. Nutrients 2 (11): 1106-1131.

Wan Mohtar WAA-QI, Hamid AA, Abd-Aziz S, Muhamad SKS, Saari N. 2014. Preparation of bioactive peptides with high angiotensinconverting enzyme inhibitory activity from winged bean [Psophocarpus tetragonolobus (L.) DC.] seed. J Food Sci Technol 51 (12): 3658-3668. DOI: 10.1007/s13197-012-0919-1.

Wang Y, Zhao C, Li J, Liang Y, Yang R, Liu J, Ma Z, Wu L. 2018. Evaluation of biochemical components and antioxidant capacity of different kiwifruit (Actinidia spp.) genotypes grown in China. Biotechnol Biotechnol Equip 32 (3): 558-565.

Zakuan Z, Mustapa SA, Sukor R, Rukayadi Y. 2018. Antifungal activity of Boesenbergia rotunda (temukunci) extracts against filamentous spoilage fungi from vegetables. Intl Food Res J 25 (1): 433-438.

Zhang H, Yang Y, Zhou Z. 2018. Phenolic and flavonoid contents of mandarin (Citrus reticulata Blanco) fruit tissues and their antioxidant capacity as evaluated by DPPH and ABTS methods. J Integr Agric 17 (1): 256-263. DOI: 10.1016/S2095-3119(17)61664-2. 